\section{UG1 Turnip Germplasm Possessing Resistance to Turnip Mosaic Virus}

\author{
V.I. Shattuck \\ Department of Horticultural Sciences, University of Guelph, Guelph, \\ Ont. N1G 2W1, Canada
}

Additional index words. Brassica rapa ssp. rapifera, disease resistance, vegetable breeding

Turnip mosaic virus (TuMV) was first described in North America on turnip (Brassica rapa L. ssp. rapifera) (Gardner and Kendrick, 1921) and other cruciferous plants (Schultz, 1921). Since that time, outbreaks of this virus have periodically occurred on many horticultural crops (Shattuck, 1992). Several studies have identified TuMV-C ${ }_{3}$ as a major strain occurring in North America and other parts of the world (Provvidenti, 1980; Stobbs and Shattuck, 1989). When susceptible crops are grown in areas where $\mathrm{TuMV}-\mathrm{C}_{3}$ is established, severe production losses can occur.

Most turnip cultivars grown commercially in North America are susceptible to TuMV$\mathrm{C}_{3}$. Infected plants may be stunted, possess mottled and malformed leaves, delayed root maturity, and altered raw root flavor. The severity of plant symptoms depends on the genotype of the plant, the developmental stage when plants are infected, and the environmental conditions during plant growth. The UG1 turnip germplasm described here represents the culmination of the first breeding effort in North America to incorporate TuMV resistance into turnip. UG1 turnip is being released since it has potential for direct use in home gardens in areas where TuMV- $\mathrm{C}_{3}$ is a problem and as a promising population for breeders to extract $\mathrm{TuMV}-\mathrm{C}_{3}$-resistant lines.

\section{Origin}

The TuMV- $\mathrm{C}_{3}$ resistance in UG1 turnip was derived from an intraspecific cross with TuMV-resistant Chinese cabbage ( $B$. rapa L. ssp. pekinensis). Although turnip and Chinese cabbage $(2 n=20)$ both possess the A crucifer genome (U, 1935), differences in chromosome morphology between these two subspecies have been noted. Richharia (1937) explored the morphological differences among the 20 chromosome species of Brassica and reported that turnip had $3 \mathrm{E}$ and $2 \mathrm{~F}$ chromosomes, whereas Chinese cabbage had $2 \mathrm{E}$ and $3 \mathrm{~F}$ chromosomes; the other chromosomes were similar. When these subspecies were hybridized, nonrandom pairing of chromosomes occasionally occurred.

The parents used in the initial hybridiza-

Received for publication 2.5 Sept. 1991. Accepted for publication 18 Mar. 1992. The cost of publishing this paper was defrayed in part by the payment of page charges. Under postal regulations, this paper therefore must be hereby marked $a d$ vertisement solely to indicate this fact. tion for this study were green 'Chen-Chen' $\mathrm{F}_{1}$, Chinese cabbage (C-C), which originated from China (seeds supplied by K. Proudfoot, Agriculture Canada, St. John's, Nfld.), and 'Purple Top White Globe' turnip (PTWG), the most widely grown turnip cultivar in North America. 'Chen-Chen' was used because it showed high resistance to the TuMV-C ${ }_{3}$ strain during vegetative development. The PTWG parents were selected for root shape, color, and uniformity before use in this research.

Ten C-C and 10 PTWG plants were reciprocally intercrossed in 1986, and the seeds collected and bulked. Two generations of backcrossing $\left(\mathrm{BC}_{2}\right)$ were conducted thereafter, with PTWG as the recurrent parent. In each backcross generation $\approx 50$ plants were grown in the greenhouse, vernalized for 2.5 months at 0 to $1 \mathrm{C}$, and selected for normal plant vigor. Seeds of the $\mathrm{BC}_{2}$ generation were bulked, and $\approx 1250$ plants from this breeding population were grown at the Horticultural Research Station in Cambridge, Ont. The plants were grown on Fox sandy loam soil under the cultural practices of the region. Natural rainfall was supplemented by sprinkler irrigation when required. Plants were manually inoculated twice with the TuMV$\mathrm{C}_{3}$ strain, at 25 and 35 days after planting. By day 45, most susceptible plants showed disease symptoms. Plants in this population were observed to segregate widely for plant morphology and TuMV-C, disease symp-
Fig. 1. Storage roots of UG1 turnip. toms. Symptomology varied from leaf mottling to necrotic flecking on the leaves and petioles. At harvest, 32 plants $(<3 \%$ of the population) were selected that showed faint TuMV symptoms while having a globe-shaped root with a diameter $>7 \mathrm{~cm}$. These roots were vernalized $[0$ to $1 \mathrm{C},>92 \%$ relative humidity (RI-I)] for 3 months and planted in the greenhouse. Resulting plants $(>700)$ were selfed and grown in progeny rows the following summer at the Horticultural Research Station. Seedlings were manually inoculated once with $\mathrm{TuMV}-\mathrm{C}_{3}, 22$ days after sowing. At harvest, $\approx 3 \%$ of the population was selected that lacked systemic mosaic and necrotic virus symptoms (Shattuck, 1991), while having a single neck and a globe-shaped root $>7 \mathrm{~cm}$ in diameter, with purple shoulders, white bottoms, and a small single tap root. The roots from these plants were vernalized for 3 months, then planted in the greenhouse. Four plants showing mild systemic mosaic virus symptoms during anthesis were selfed through bud pollination, and the seeds were bulked. UG1 turnip is the result of two cycles of mass selection for TuMV- ${ }_{3}$ resistance and root morphology from this initial bulked seed in outdoor breeding plots at the Horticultural Research Station. In each cycle, selected plants were manually selfed and intercrossed in the greenhouse.

\section{Description}

UG1 plants possess vigorous tops with a harvest index (i.e., dry weight ratio of storage root to foliage and storage root) from 0.45 to 0.60 . Root sizing is generally slower than for PTWG, but leaf shape is similar to PTWG. Foliage growth habit varies from upright to prostrate, and petiole length and color are also variable. Plants possess high resistance to the TuMV- $\mathrm{C}_{3}$ strain during the vegetative growth stage, with no visual symptoms. During flowering, mild or transitory systemic mosaic symptoms may become visible at various times on leaves of

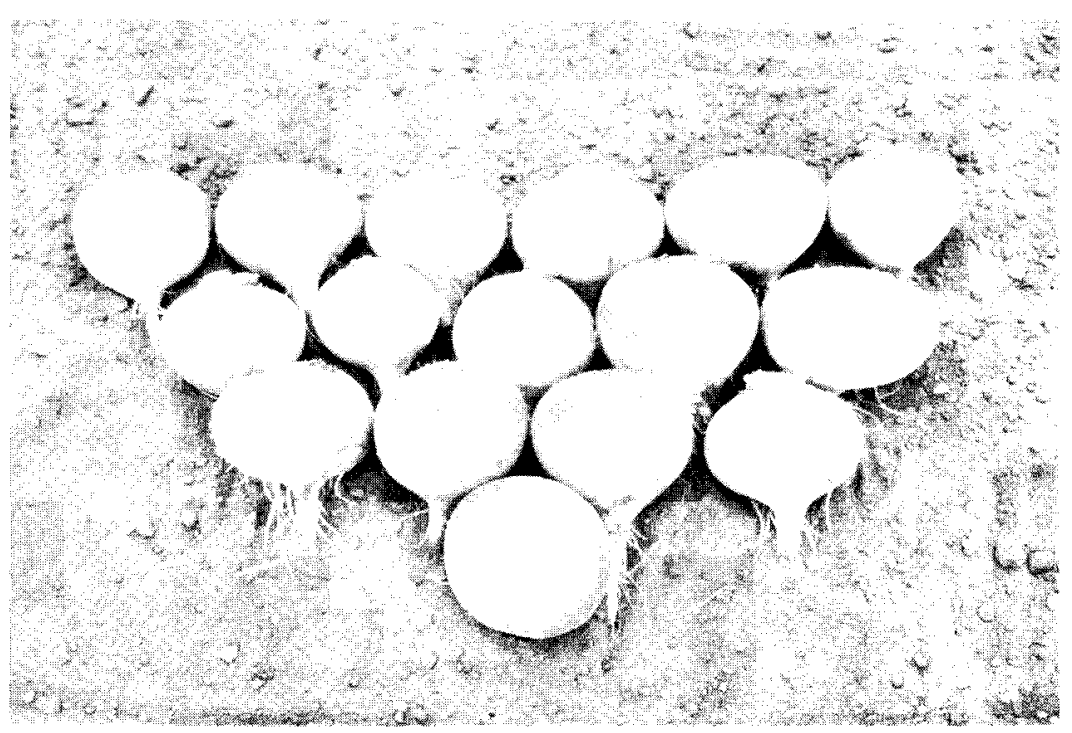


plants. Enzyme-linked immunosorbent assay testing has revealed variable levels of virus titer in UGl plants at flowering that are lower than found in TuMV-C $\mathrm{C}_{3}$-infected PTWG.

Mature UG1 plants produce firm, smooth, globular to flattened round roots with purple shoulders, white bottoms, and a single tap root (Fig. 1). The interior of the roots is bright white. Roots exhibit resistance to root splitting and cracking, and the raw root flavor is mild and sweet. Preliminary data indicate that roots retain firmness following 3 months of storage ( 0 to $1 \mathrm{C}$, >92\% RH). Vernalized plants produce a single inflorescence, ample pollen, and numerous siliques. Although UG1 turnip was not examined cytologically for possible irregularities in chro- mosome pairing, the ample pollen production of plants suggests that this should not be a problem. UG1 turnips consist of both selffertile and self-incompatible plants.

\section{Availability}

Contact V.I.S. to inquire about small seed lots for research purposes.

\section{Literature Cited}

Gardner, M.W. and J.B. Kendrick. 1921. Turnip mosaic. J. Agr. Res. 22:123-124.

Prowidenti, R. 1980. Evaluation of Chinese cabbage cultivars from Japan and the People's Republic of China for resistance to turnip mosaic virus and cauliflower mosaic virus. J. Amer
Sot. Hort. Sci. 105:571-573.

Richharia, R.H. 1937. Cytological investigations of 20 chromosome species of Brassica and their $\mathrm{F}_{1}$ hybrids. J. Genet. 34:145-55.

Schultz, E.S. 1921. A transmissible mosaic disease of Chinese cabbage, mustard and turnip. J. Agr. Res. 22:173-177.

Shattuck, V.I. 1992. The biology, epidemiology and control of turnip mosaic virus. Hort. Rev. 14 (In press.)

Stobbs, L.W. and V.I. Shattuck. 1989. Turnip mosaic virus strains in southern Ontario, Canada. Plant Dis. 73:208-212.

U., N. 1935. Genome analysis in Brassica with special reference to the experimental formation of $B$. napus and peculiar mode of fertilization. Jpn. J. Bot. 7:389-452. 